\title{
COMENTÁRIOS DA NARRATIVA DE ATOS 13. 14-41; 14. 14-18; 17. 22-34; 22. 1-24 PELA PERSPECTIVA TEÓRICA DE GÉRARD GENETTE ${ }^{1}$
}

\author{
Luciene de Lima Oliveira* \\ (Universidade do Estado do Rio de Janeiro)
}

\begin{abstract}
RESUMO: Gérard Genette conceitua a narrativa como a representação de um acontecimento ou de vários acontecimentos, considerados reais ou fictícios, por meio da linguagem e, principalmente, da linguagem escrita (GENETTE, 2011, p. 265). A estrutura da narrativa, em Genette, é analisada tendo por referências três categorias, que são fundamentadas no(a): tempo, modo e voz. Assim é que o presente artigo tem por escopo tecer comentários de alguns excertos do livro de Atos dos Apóstolos pelo viés teórico de Gérard Genette.
\end{abstract}

Palavras-Chave: Narrativa, Gérard Genette, Atos, Discurso.

\section{COMMENTARY ON THE NARRATIVE OF ACTS 13. 14-41; 14. 14-18; 17. 22-34; 22. 1-24 BY THE THEORETICAL PERSPECTIVE OF GÉRARD GENETTE}

\begin{abstract}
Gérard Genette understands the narrative as the representation of an event or several events, either fictional or real, by means of language, and more importantly, written language (GENETTE, 2011, p. 265). The structure of the narrative, in Genette, is analysed by having as reference three categories substantiated in: time, mode and voice. Thus, the scope of the present article comments on some excerpts of the book of Acts of the Apostles by Gérard Genette's theoretical approach.

KEYwORDS: Narrative, Gérard Genette, Acts, Discourse.
\end{abstract}

Gérard Genette conceitua a narrativa como a representação de um acontecimento ou de vários acontecimentos, considerados reais ou fictícios, por meio da linguagem e, principalmente, da linguagem escrita (GENETTE, 2011, p. 265).

Já, Samira Mesquita diz que a narrativa constitui o "ato verbal de apresentar uma situação inicial que, passando por várias transformações, chega a uma situação final”, sendo que essas transformações são originadas por acontecimentos, fatos, vivências, episódios etc (MESQUITA, 1987, p. 21).

\footnotetext{
${ }^{1} \mathrm{O}$ presente artigo constitui uma adaptação de algumas partes da Tese de Doutorado intitulada Os Discursos Epidícticos de Paulo de Tarso No Livro dos Atos dos Apóstolos (Tradução e Comentários), defendida em fevereiro de 2016, sob a orientação do Professor Doutor Auto Lyra Teixeira no PPGLC da UFRJ.

*E-mail: lucienedelimaoliveira@yahoo.com.br 
Convém destacar a existência da seguinte tríade: a narrativa (que é o significante, o enunciado, o discurso ou o texto narrativo em si), a narração (que é o ato narrativo produtor e, mais amplamente, o conjunto da situação real ou fictícia) e a história (que é o significado ou o conteúdo narrativo).

A narração está vinculada às ações ou aos acontecimentos que são vistos como processos puros, e, por essa causa, o aspecto temporal e dramático da narrativa é acentuado (GENETTE, 2011, p. 25; p. 275).

A estrutura da narrativa, em Genette, é analisada tendo por referências três categorias, que possuem ligações entre si. Sublinhe-se que estas categorias são fundamentadas no(a):

1) Tempo - relação temporal entre a história (isto é, os acontecimentos) e a narrativa (como esses acontecimentos são narrados).

Entrementes, denominam-se anacronias narrativas as variadas formas de discordância entre a ordem da história e da narrativa (ibidem, p. 34). Na verdade, a anacronia é considerada um dos recursos tradicionais da narração literária.

Como sublinha Brait, "é inevitável iniciar uma reflexão teórica sem voltar o olhar para a Grécia Antiga e para os pensadores que impulsionaram o conhecimento" (BRAIT, 1990, p. 28). Assim é que Genette dá, como exemplo de anacronia, os primeiros versos da Ilíada (HOMÈRE. Iliade I, 11-12).

Genette lembra que o primeiro objeto narrativo mencionado por Homero era a "cólera de Aquiles"; o segundo, "as desgraças dos Aqueus", que são a consequência da cólera; o terceiro é a "querela entre Aquiles e Agamêmnon" que é a causa imediata da cólera, sendo, portanto, anterior à cólera; há a "peste" e, por fim, "o ultraje ao sacerdote de Apolo", Crises, ultraje esse que foi a causa da peste. Assim, os cinco elementos que formam os versos iniciais da epopeia, o estudioso nomeia de "A, B, C, D, E" de acordo com a ordem que aparecem no relato, mas aparecem na história nas seguintes posições cronológicas “ $4,5,3,2,1$ ”. Ora, constitui, então, uma narrativa in medias res, isto é, Homero opta pela não linearidade

O estudioso pontua que o motivo para que haja a presença dessas anacronias, é devido ao fato da narrativa ser uma sequência "duas vezes temporal", uma vez que há o tempo da "coisa-contada" e o tempo da narrativa (GENETTE, 1995, pp. 31-36).

Ressalte-se que essas anacronias se revelam sob duas formas: pelo emprego da analepse que é o relato dos acontecimentos anteriores em relação ao tempo presente da história contada ou da prolepse que é toda manobra narrativa que consiste em contar, antecipadamente, um acontecimento posterior.

Todorov destaca que o autor, na maior parte do tempo, não tenta fazer uma "sucessão natural", porque ele pode utilizar a deformação temporal para fins estéticos (TODOROV, 2011 b, p. 242).

Convém pontuar a existência da anisocronia que significa que o tempo narrativo possui uma duração diferente do da história. Ao contrário da isocronia, cuja ordem do discurso acompanha a ordem temporal. Assim é que a anisocronia é um processo que se vê uma modificação no ritmo da narrativa, emprega-se para tal, os seguintes recursos: os resumos ou os sumários, que é uma redução do tempo da história com a narração em parágrafos menores ou páginas de, por exemplo, vários dias, meses ou anos sem haver detalhes das ações ou das palavras; as elipses, que são as omissões de certos acontecimentos ou de períodos da história; as pausas, que são determinadas interrupções da história com o objetivo de dar lugar às descrições ou às divagações.

Com isso, a anisocronia pode ocorrer também com as digressões, quando o narrador faz prolongar o tempo da história através das descrições adicionais, ocorrendo, então, certos desvios do assunto em questão para outro diverso daquele de que se tratava. 
2) Modo - Todorov diz que o modo da narrativa é o tipo de discurso que o narrador utiliza para se fazer conhecer a história (TODOROV, 2011 b, p. 241).

A informação narrativa se caracteriza por alguns graus, uma vez que a história contada pode oferecer ao leitor determinados detalhes em diferentes distâncias que conta. Assim é que a "distância" e a "perspectiva" constituem as duas modalidades essenciais da regulação da informação narrativa, que é o modo.

a) A Distância - denomina-se distância ao espaço que o narrador coloca no que diz respeito à história narrada. Ora, esse narrador pode relatar uma história, incluindo-se nela ou se ausentando da mesma.

Destarte, Genette sublinha que se tem, em Platão, uma abordagem dos problemas de distância (GENETTE, 1995, p. 160). Platão considera, por simples narrativa, tudo aquilo que o poeta narra, sem procurar fazer crer que seja um outro que fala (PLATO. Republic 3.393 a). Tem-se, então, a narrativa pura, quando o poeta fala por si ( $c f$. o discurso indireto) e a narrativa imitativa ou mimética, quando o poeta dá a fala a uma personagem ( $c f$. o discurso direto).

De acordo com Platão, Homero poderia ter dado continuidade à sua história sob uma forma, estritamente, narrativa, narrando as palavras de Crises, ao invés de reproduzí-las (PLATO. Republic 3. 393 b, c, d).

Assim é que não se podem separar os três pólos de referência: "quem imita, com que imita, o que imita. Também não podemos separar o imitador, a imitação, o imitado" (CASTRO, 1986, p. 58).

Genette ressalta que:

A linguagem só pode imitar, perfeitamente, a linguagem ou, mais precisamente, o discurso só pode imitar, perfeitamente, um discurso, perfeitamente, idêntico; em resumo, um discurso só pode imitar ele mesmo. Enquanto lexis, a imitação direta é, exatamente, uma tautologia (GENETTE, 2011, p. 271).

Em um discurso, alguém fala, mas, em uma narrativa, conforme Benveniste, pode-se dizer que ninguém fala, no sentido de que, em nenhum momento, pergunta-se "quem fala" (onde e quando, etc.), para que receba, de modo integral, a significação do texto (BENVENISTE apud GENETTE, 2011, p. 280).

Assim é que Genette faz uma oposição entre narrativa mimética e narrativa pura, fazendo uma tríplice divisão dos estados do discurso: a) O Discurso Narrativizado ou Contado em que o próprio narrador conta; b) O Discurso Transposto que é considerado um discurso intermediário entre o discurso narrativizado e o imitado, com uma pequena presença de um narrador; c) $O$ Discurso Imitado que é o discurso fictício. Na verdade, acredita-se que tenha sido pronunciado, na íntegra, pela personagem, o "narrador finge ceder, literalmente, à palavra à sua personagem" (GENETTE, 1995, pp. 169-170).

Há, normalmente, três tipos de estratégias apresentadas pelos gramáticos para fazer citações: o discurso indireto, o discurso indireto livre e o discurso direto.

No discurso indireto, o enunciador dá a sua versão do discurso de um locutor, analisando o discurso ou o texto de outrem.

O discurso indireto livre é uma combinação do discurso direto e do indireto. De acordo com o linguista francês Maingueneau, há textos em discurso indireto livre mais próximo do discurso direto e outros mais próximos do indireto (MAINGUENEAU, 1986, p. 99).

No discurso indireto livre, o narrador assume o discurso da personagem ou se prefere, a personagem fala pela voz do narrador; assim, as instâncias se mesclam.

Por outro lado, o discurso direto é uma enunciação construída por intermédio do discurso do narrador. Benveniste insere, na categoria do discurso, tudo aquilo que Aristóteles 
denominava imitação direta, que consistia em um discurso que o poeta ou o narrador emprestavam a um de seus personagens (BENVENISTE apud GENETTE, 2011, p 278).

Ora, Todorov é enfático:

O encaixe é uma explicitação da propriedade mais profunda da narrativa. Pois a narrativa encaixante é a narrativa de uma narrativa. Contando a história de uma outra narrativa, a primeira atinge seu tema essencial e, ao mesmo tempo, se reflete nessa imagem de si mesma; a narrativa encaixada é, ao mesmo tempo, a imagem dessa grande narrativa abstrata da qual todas as outras são apenas partes ínfimas, e também da narrativa encaixante, que a precede diretamente (TODOROV, 2011 a, p. 126).

b) A Perspectiva - é o "segundo o modo de regulação da informação, que procede da escolha (ou não) de um "ponto de vista" restritivo" (GENETTE, 1995, p. 183).

Todorov emprega três termos (fórmulas): a) Narrador > Personagem, tradicionalmente conhecido como o "narrador onisciente" ou "visão por trás", o narrador sabe mais que o personagem; b) Narrador = Personagem em que o narrador só diz aquilo que o personagem sabe; c) Narrador < Personagem em que o narrador diz menos daquilo que o personagem sabe (TODOROV, 2011 b, pp. 246-248).

Então, podem-se estabelecer três tipos de narrativa, tendo em vista a focalização: 1) narrativa de focalização onisciente - o narrador conta a história de um ponto de vista superior, como se possuísse um conhecimento total e ilimitado. Todorov lembra que a narrativa clássica emprega, frequentemente, esta fórmula (TODOROV, 2011 b, p. 246); 2) narrativa de focalização interna - quando a personagem é o sujeito da enunciação; 3) narrativa de focalização externa - sabem-se as ações das personagens, sem conhecer sobre seus pensamentos.

3) $\boldsymbol{V o z}$ - É como se dá a narração dentro da narrativa, levando em consideração dois aspectos: por quem (= narrador) e para quem (= narratário ou destinatário real ou fictício) os acontecimentos são relatados. Todorov destaca que o aspecto reflete uma relação entre "um ele" (na história) e "um eu" (no discurso), entre a personagem e o narrador (TODOROV, 2011 b, p. 246).

$\mathrm{Na}$ verdade, os aspectos e os modos da narrativa constituem duas categorias que possuem ligações estreitas em que ambos dizem respeito à imagem do narrador (ibidem, 2011 b, p. 254).

Barthes destaca que não pode haver narrativa sem narrador e sem ouvinte ou leitor (BARTHES, 2011, p. 48).

Genette apresenta determinados tipos de narrador que se dividem em relação ao nível narrativo (intra-/extradiegético) e quanto à sua relação na história (homo-/heterodiegético) (GENETTE, 1995, p. 226 ss). Assim, há quatro tipos de narrador (ibidem, p. 247):

1) Extradiegético-Heterodiegético - narrador do primeiro nível (primário) que relata uma história sem ter participado da mesma, pois está ausente.

2) Extradiegético-Homodiegético - narrador do primeiro nível (primário) que conta a sua própria história. No caso do narrador homodiegético é dividido em dois grupos: tanto ele pode ser um simples observador, exercendo um papel secundário, como também a personagem principal de sua própria história (autodiegético), contando suas próprias experiências.

3) Intradiegético-Heterodiegético - narrador do segundo grau (secundário) que relata uma história da qual, normalmente, não teve participação, pois está ausente.

4) Intradiegético-Homodiegético - narrador do segundo grau (secundário) que conta a sua própria história.

Beth Brait destaca que a apresentação de uma personagem, cujo narrador não se insere dentro da história, constitui um recurso muito antigo e eficaz. A crítica literária pontua, ainda, 
que é um artifício primeiro, uma tentativa de criar uma história que deve alcançar a credibilidade do leitor e oferece, como exemplos, o Antigo Testamento, as epopeias clássicas e os contos de fada, onde a personagem não se apresenta por si mesma, mas por suas aventuras, através do relato das suas ações (BRAIT, 1990, p. 55).

É bom lembrar que, na realidade, mesmo os corpora escritos não constituem uma oralidade enfraquecida, mas algo dotado de uma "voz", a de um sujeito situado para além do texto. Embora o texto seja escrito, ele é sustentado por uma voz específica: "a oralidade não é o falado", como lembra Meschonnic (MESCHONNIC, 1985, pp. 121-128).

Em relação ao narratário, Genette sublinha que, assim como o narrador, o narratário além de ser um dos elementos da situação narrativa, está situado no mesmo nível diegético. No quadro subscrito, têm-se os seguintes tipos de narratários (GENETTE, 1995, pp. 258-259):

1) Extradiegético-Heterodiegético - narratário do primeiro nível (primário) que ouve uma história sem ter participado da mesma.

2) Extradiegético-Homodiegético - narratário do primeiro nível (primário) que ouve uma história da qual vivenciou.

3) Intradiegético-Heterodiegético - narratário do segundo grau (secundário) que ouve uma história da qual, normalmente, não teve participação.

4) Intradiegético-Homodiegético - narratário do segundo grau (secundário) que ouve uma história que vivenciou.

Todorov, assim, discorre acerca da figura do narrador: "É ele que dispõe certas descrições antes das outras, embora estas as precedam no tempo da história. É ele que nos faz ver a ação pelos olhos de tal ou tal personagem. É ele, enfim, que escolhe relatar-nos tal peripécia através do diálogo de dois personagens ou mesmo por uma descrição "objetiva".

Para o linguista búlgaro, a imagem do narrador e a do leitor está em dependência mútua; a partir do momento que a imagem do narrador sobressai de modo mais nítido, a imagem do leitor "imaginário" encontra desenhado, igualmente, com mais precisão (TODOROV, 2011 b, pp. 255-257).

Quanto aos excertos de Atos 13. 14-41; 14. 14-18; 17. 22-34; 22. 1-24, que serão comentados pelo viés teórico de Gérard Genette, se encontram registrados no livro dos Atos dos Apóstolos, que abrange um período de um pouco mais de 30 anos (de 29 a 61 d.C.), das origens do estabelecimento da Igreja Cristã à prisão de Paulo em Roma. O livro dos Atos foi redigido em grego koiné, provavelmente, entre os anos 60 e 63 d.C.

Sublinhe-se que o quinto livro do Novo Testamento possui um narrador primário, Lucas, e um narratário, igualmente primário, Teófilo. Lucas, supostamente, um médico gentio, teria testemunhado muitos dos fatos que registrou em sua obra. Ele era também amigo de Paulo, se levarmos em consideração Filemon 24, Colossenses 4.14 e Segunda Epístola a Timóteo 4. 11), e o teria acompanhado, quando o apóstolo empreendeu sua segunda viagem missionária, conforme constatamos em Atos 16. 11-18.

Em um determinado momento de sua narrativa, Lucas reproduz alguns discursos. Ressalte-se que os quatro discursos paulinos, que constituem o corpus da pesquisa, são miméticos ${ }^{2}$, isto é, reproduzidos pelo narrador primário.

É bom citar Saussure, o qual atesta que a língua e a escrita são dois sistemas distintos de signos; em que o segundo representa o primeiro. O linguista francês faz a seguinte assertiva: "a palavra escrita se mistura, tão intimamente, com a palavra falada, da qual é a imagem, que acaba por usurpar-lhe o papel principal" (SAUSSURE, 2012, p. 58).

Tem-se as seguintes informações dos quatro discursos paulinos miméticos, isto é, reproduzidos pelo narrador primário, Lucas:

\footnotetext{
${ }^{2}$ Platão emprega os termos diegéseis mimouménous (PLATO. Republic 3.394 d) e miméseos tên diégesin, para se referir aos discursos/relatos imitados/reproduzidos por Homero e outros poetas (PLATO. Republic 3. 393 c).
} 
1. O discurso em Antioquia da Pisídia (At 13. 14-41)

A introdução dos discursos reproduzidos por parte do narrador primário:

14 Ora, eles ${ }^{3}$, atravessando (ao longo de) Perge, dirigiram-se para Antioquia da Pisídia, e, entrando na sinagoga em dia de sábado, assentaram. 15 Então, após a leitura da lei e dos profetas, os chefes da sinagoga mandaram dizer-lhes: "Ó varões irmãos, se há alguma palavra de exortação entre vós para o povo, falai". 16 E ainda, Paulo, após ter se levantado e feito sinal com a mão, disse (...).

\section{A finalização dos discursos reproduzidos por parte do narrador primário:}

[42] Então, após eles terem saído, pediam que fossem ditas estas mesmas palavras no sábado seguinte. [43] E ainda, quando a sinagoga foi dispersa, muitos dos judeus e dos devotos prosélitos acompanharam a Paulo e a Barnabé, os quais, conversando com eles, os persuadiam a permanecer na graça de Deus.

2. O discurso em Listra para a multidão (At 14. 14-18)

A introdução dos discursos reproduzidos por parte do narrador primário:

[14] Então, os apóstolos Barnabé e Paulo, após terem ouvido, rasgando as suas vestes exteriores, correram para a multidão, bradando [15] e dizendo (...).

A finalização dos discursos reproduzidos por parte do narrador primário:

[18] E, falando essas coisas com dificuldade, fizeram desistir as multidões para que não lhes sacrificassem matando a(s) vítima(s).

3. O discurso no Areópago de Atenas (At 17. 22-34)

A introdução dos discursos reproduzidos por parte do narrador primário:

[22] Então, Paulo, estando de pé, no meio do Areópago, dizia (...).

A finalização dos discursos reproduzidos por parte do narrador primário:

[32] Então, após terem ouvido (a respeito) da ressurreição de mortos, uns escarneciam, outros disseram: "te ouviremos a respeito disso também em uma outra ocasião". [33] Deste modo, Paulo saiu do meio deles. [34] E, ainda, alguns homens, se associando a ele, creram, entre os quais também Dionísio, o Areopagita, e uma mulher de nome Damaris e outros com eles.

4. O discurso nas escadarias da Fortaleza Antônia em Jerusalém (At 22. 1-24)

A introdução dos discursos reproduzidos por parte do narrador primário:

[40] Ora, ele ${ }^{4}$ após ter permitido, Paulo, estando de pé sobre os degraus, fez sinal com a mão ao povo. Então, grande silêncio foi feito (quando) dirigiu a palavra em dialeto hebraico, dizendo (...).

Após o breve proêmio de Paulo em Atos 22. 1, o narrador interrompe o discurso para fazer uma observação que achou importante no próximo versículo:

[2] E ainda, quando ouviram que lhes dirigia a palavra em dialeto hebraico, demonstraram mais tranquilidade. E dizia (...).

\footnotetext{
${ }^{3}$ Em uma referência a Paulo e a Barnabé.

${ }^{4}$ Em uma referência ao comandante Cláudio Lísias.
} 
No versículo 22, o narrador encerra o discurso nestes termos:

[22] Então, ouviram até esta palavra dele e ergueram a voz deles, dizendo: 'Remova o tal da terra, pois não convém que ele viva'. [23] Tanto eles gritavam quanto arremessavam as vestes e ainda lançavam pó para o ar. [24] O comandante ordenou que ele fosse conduzido para a fortaleza, dizendo que ele fosse interrogado com açoites, para que conhecesse completamente (o) motivo pelo qual berravam daquele modo (contra) ele.

A propósito, pode-se entender o artifício mimético dos discursos pelo viés da sincronia, uma vez que é como se o orador estivesse falando naquele dado momento da narrativa, isto é, simultaneamente aos fatos narrados pelo narrador.

Sublinhe-se que a língua é um sistema que funciona: 1) em um momento temporal (sincronia); 2) ou analisada em sua evolução (diacronia) (DUBOIS et alli, 1970, p. 181).

Como se infere do estudo da narratologia dos Atos dos Apóstolos, encontra-se um narrador primário (Lucas) e um narratário, igualmente primário, Teófilo. Não obstante, no decorrer de sua narrativa, o narrador insere determinados narradores secundários que conduzem a narrativa e os narratários, igualmente, secundários.

Ressalte-se que o narrador primário dos Atos é um "narrador onisciente" que conta a história de um ponto de vista superior ( $c f$. narrativa de "focalização onisciente"). Possui um domínio total e ilimitado de toda a história, conhecendo, com detalhes, os fatos do presente, do futuro e, principalmente, do passado. Tem acesso às ações e aos pensamentos das personagens que aparecem em sua narrativa (At 2. 37, 43; 3. 1-10; 8. 1; 9. 1-9, 23; 10. 17; 12. 9. 20. 16; 23. 12,10 ). O médico também revela o fim da história (At $5.11 ; 8.13,40 ; 10.48 ; 12.19,25 ; 14$. 21).

Lucas, assim, é um narrador extra-heterodiegético, distante daquilo que escreve, isto é, ausente de certos acontecimentos. Entrementes, se for Lucas nos excertos das "seções-nós", ele passa a ser um narrador extra-homodiegético que relata uma história, da qual teve uma participação.

Não obstante, se for levado em conta que o "nós" nos excertos das "seções-nós" seja um personagem coletivo do relato, é classificado como "intra-homodiegético". Assim, não constitui um narrador totalmente alheio e distante daquilo que escreve ( $f f$. narrativa de focalização interna, quando a personagem é o sujeito da enunciação).

Teófilo é um narratário primário extra-heterodiegético, pois escuta, ou melhor, lê uma história sem ter participado da mesma, uma vez que não há evidências da presença de Teófilo no decorrer da narrativa dos Atos.

Destacam-se, ainda, na narrativa dos Atos, além das anacronias narrativas, os discursos em forma de prédicas.

Levando em conta as informações contidas na narração do discurso paulino na Sinagoga em Antioquia da Pisídia (Atos 13. 14-41), pode-se considerar que Paulo é tanto um narrador secundário intra-heterodiegético, em grande parte do seu discurso (quando se distancia dos fatos relatados por ele) quanto é intra-homodiegético (quando vivencia os fatos relatados por ele), como por exemplo: o emprego de pronomes e de verbos na primeira pessoa do plural, "a nós" (vers. 26); "nós vos anunciamos o Evangelho" (vers. 32), se inserindo assim no próprio relato, conforme: “(...) a palavra desta salvação foi enviada a nós (At 13. 26)”; "E nós vos anunciamos o Evangelho da promessa feita aos pais (At 13.32)".

Lucas deixa o discurso mimético de Paulo fluir normalmente, sem haver intromissões por parte do narrador primário. Assim é que o discurso em Antioquia da Pisídia constitui uma narrativa de focalização interna, uma vez que Paulo, o narrador secundário, é o sujeito da enunciação. 
Os ouvintes são narratários secundários tanto intra-heterodiegéticos, em grande parte do discurso paulino, pois escutam um relato em que não tiveram participação quanto intrahomodiegéticos, pois escutam uma história que estão vivenciando (quando Paulo se utiliza de pronome na primeira pessoa do plural, "a nós" (vers. 26) e na segunda pessoa do plural, "vos" (vers. 32), uma vez que o apóstolo insere o seu público dentro da história narrada por ele, estreitando, dessa forma, a distância que existe entre o orador, a história contada por ele e o seu público.

Paulo valoriza, principalmente, a história antiga de Israel, onde engrandece as boas ações da divindade que os israelitas cultuavam; exaltando, em especial, a fidelidade divina tanto na antiguidade quanto no presente (vers. 17-23; 30, 32-39). Assim, Paulo amplifica e valoriza esses fatos de modo a criar uma comunhão em torno desses valores que o seu público, de um modo geral, já conhecia. É mister lembrar que, no decorrer do seu relato da história de Israel, Paulo insere outros assuntos.

Paulo empregou os termos "promessa" (vers. 23, 32) e o binômio "Salvador/salvação" (vers. 23, 26) em lugares estratégicos de sua narração, dando a entender que, em meio a esses acontecimentos, deve ser compreendida toda a história do passado, que havia sido relatado em resumo (vers. 17-22). Ora, a concretização da promessa, feita aos antepassados, é que faz com que Israel alcance a salvação prometida.

Pode-se dizer que um dos objetivos desse discurso, "e nós vos anunciamos o Evangelho da promessa feita aos pais" (vers. 32) não era, somente, levar os judeus a reconhecerem a messianidade de Jesus, tal qual os discursos petrinos em Jerusalém (At 2. 14-36; 3. 12-26; 4. 8-12), mas levá-los a entender que o plano salvífico incluía também os gentios (vers. 39). Para isso, era de suma importância a pregação do Evangelho aos mesmos e a sua aceitação na congregação cristã.

Quanto ao discurso em Listra para a Multidão (Atos 14. 14-18), Paulo é tanto um narrador secundário intra-heterodiegético, em grande parte do seu discurso (quando se distancia dos fatos relatados por ele) quanto é intra-homodiegético (quando vivencia os fatos relatados por ele), quando empregou, por exemplo, o pronome e verbo na primeira pessoa do plural, além de um particípio no plural (vers. 15).

Os ouvintes são narratários secundários intra-heterodiegético, em grande parte do discurso paulino, pois escutam um relato que não tiveram participação quanto intrahomodiegético, pois escutam uma história que estão vivenciando, quando Paulo empregou, por exemplo, pronomes na segunda pessoa do discurso, no plural, e um infinitivo, que estão vinculados ao seu público. Desse modo, o apóstolo insere o seu público dentro da história narrada por ele, estreitando, dessa forma, a distância que existe entre o orador, a história contada por ele e o seu público. Eis o excerto que explicita tanto o narrador intra-homodiegético quanto o narratário:

Nós também somos seres humanos de semelhante natureza como vós; vos anunciamos o Evangelho, para converterdes destas coisas inúteis ao Deus vivo (vers. 15).

Lucas faz a introdução do discurso paulino e, depois, deixa o discurso mimético de Paulo fluir normalmente, sem haver intromissões. Assim é que o discurso em Listra para a multidão constitui uma narrativa de focalização interna, uma vez que Paulo, o narrador secundário é o sujeito da enunciação. Após inserir o discurso paulino, o narrador primário oferece informações sobre o resultado do discurso (At 14. 18-19).

Paulo empregou a amplificação de modo antitético, ao colocar em confronto dois pensamentos, ou melhor, uma proposição considerada "fraca", porém vista como "certa" para o seu público, e uma proposição considerada "forte", porém vista como "certa" para ele. A 
propósito, seria preciso, para esta última proposição, ser amplificada por ser a "mais forte e verdadeira". Utilizando-se de um acontecimento, que acabara de ocorrer diante dos seus olhos (At 14. 13), Paulo desenvolve as suas ideias.

O apóstolo almejava a epistrophé, uma conversão de um estilo de vida religiosa considerada "errônea" para um estilo de vida religiosa "certa", que seria incompatível com os cultos pagãos tradicionais.

Pode-se inferir que Paulo reprovou uma atitude muito comum de seu público: oferecer sacrifícios para agradar às suas divindades e intitula essa atitude de "coisas inúteis" (vers. 15). A crítica aos atos dos de Listra pode ser resumida em uma palavra grega: mátaia "inútil", "vazia", "vã". A propósito, esse adjetivo expressa muito bem o pensamento paulino.

O versículo 15 constitui o ápice da argumentação do apóstolo, pois revela-se "a proclamação", onde a função argumentativa do enunciado está mais visível nestes termos:

[15] vos anunciamos o Evangelho, para converterdes destas coisas inúteis ao Deus vivo, que criou o céu e a terra e o mar e todas as coisas existentes neles.

Ora, na concepção judaico-cristã, tem-se a seguinte ordem:

[7] E não oferecerão mais seus sacrifícios aos demônios, atrás dos quais eles andam; isto será um estatuto perpétuo para eles nas suas gerações. [8] E a eles dirás: qualquer homem da Casa de Israel e do peregrino que habitar entre eles, que oferecer oferta de elevação ou sacrifício, [9] e à porta da tenda da reunião não trouxer, para oferecê-los ao Eterno - aquele homem será banido de seu povo (Lv 17. 7-9).

Ser cristão, para os apóstolos, no mundo romano, significava não mais compactuar com as suas bases religiosas. Há um exemplo digno de nota desse pensamento que é a queima dos livros de magia (At 19. 18-19). A atitude dessas pessoas demonstra a oposição da fé cristã com as concepções religiosas vigentes (PRIETO, 2007, pp. 124-125). A propósito, escritores antigos se referem aos livros desta espécie como "escritos de fórmulas mágicas" (PLUTARCH. Quaestiones Convivales 706 e).

Paulo, para ratificar suas palavras, valoriza, principalmente, "as boas ações" do "Deus Vivo", que a multidão de Listra desconhecia. Ser o "Deus Vivo", é ser o Criador Supremo, possuir o poder de dar vida para fazer o bem e trazer chuva e sustento a todos (vers. 15-17).

$\mathrm{Na}$ narração do discurso paulino no Areópago de Atenas, Paulo é tanto um narrador secundário intra-homodiegético quanto intra-heterodiegético. É intra-homodiegético, quando vivencia os fatos relatados por ele, como, por exemplo:

[22] Então, Paulo, estando de pé, no meio do Areópago, dizia: “Ó varões Atenienses, de acordo com todas as coisas, vejo-vos como extremamente religiosos. [23] Pois, passando e observando atentamente os vossos objetos de culto, encontrei também um altar, no qual estava escrito: "Ao Deus Desconhecido". Por conseguinte, aquilo que, não conhecendo, adorais, isto eu anuncio a vós (At 17. 22-23).

Podem-se extrair os seguintes verbos e pronomes que dizem respeito a Paulo: "vejo" (vers. 22), "passando e observando atentamente", "encontrei", "eu anuncio" (vers. 23).

Paulo é, de igual modo, um narrador intra-heterodiegético, quando se distancia dos fatos relatados por ele como, por exemplo, quando ele dircursa a respeito do "Deus Desconhecido" (At 17. 24-27; 30-31). 
É bom lembrar que, do final do versículo 27 até o versículo 29, o orador Paulo insere não só ele quanto os seus ouvintes na narração, por meio do pronome de primeira pessoa do plural e de verbos, igualmente, na primeira pessoa do plural do discurso, conforme o excerto subscrito:

[27] (...) se bem que não esteja distante de cada um de nós. [28] De fato, nele, vivemos e movemos e existimos, como também alguns dentre os vossos poetas falaram: Também, com efeito, somos descendência dele. [29] Portanto, sendo descendência de Deus, não devemos pensar que a divindade seja semelhante à imagem de ouro (...).

Assim, o apóstolo volta a ser um narrador secundário intra-homodiegético e os seus ouvintes são narratários secundários, igualmente intra-homodiegéticos.

É mister lembrar que os seus ouvintes, em uma outra ocasião, foram narratários secundários intra-homodiegéticos, pois foram personagens da observação de Paulo (vers. 2223). Podem-se extrair os seguintes verbos e pronomes que dizem respeito aos narratáriosouvintes: "(...) como extremamente religiosos", "vos" (vers. 22); "os vossos objetos de culto", "não conhecendo, adorais", "a vós" (vers. 23).

Sublinhe-se que os seus ouvintes são também intra-heterodiegéticos, pois escutam um relato, do qual, normalmente, não tiveram participação, principalmente, quando Paulo disserta a respeito do "Deus Desconhecido" (At 17. 24-27; 30-31).

Lucas deixa o discurso mimético de Paulo fluir normalmente, sem haver intromissões por parte do narrador primário. Assim é que o discurso no Areópago de Atenas constitui uma narrativa de focalização interna, uma vez que Paulo, o narrador secundário é o sujeito da enunciação. Não obstante, convém ressaltar que, após o narrador secundário, Paulo, abordar o assunto da ressurreição (vers. 31), o narrador primário se intromete na narração para dar certas informações finais (vers. 32-34).

Paulo empregou a amplificação de modo antitético, tal qual fez, anteriormente, em seu discurso em Listra. A propósito, foi justamente a devoção dos atenienses que inspirou Paulo em seu discurso no Areópago.

Tal qual em seu discurso em Listra, Paulo almejava a epistrophé, uma conversão de um estilo de vida religiosa considerada "errônea" para um estilo de vida religiosa "certa", que seria incompatível com os cultos tradicionais, conforme já foi dito. Assim, seu discurso é uma chamada para a aceitação de uma nova maneira de vida e um abandono da "idolatria pagã" (cf. metánoia, vers. 30). De certo, a mesma inscrição sob a qual Paulo, inicialmente, baseava sua defesa "Ao Deus Desconhecido" proporciona, ao final do discurso, uma critica dos hábitos religiosos como uma "idolatria ignorante" (ROWE, 2009, p. 41).

Paulo enfatiza que, apesar de os seres humanos serem filhos do "Deus Desconhecido", não se deve criar a imagem divina concebida em ouro, em prata e em pedra. Representações essas são próprias do talento e do poder imaginativo humano (At 17.29), uma vez que não se pode retratar a noção de divindade através da humanidade.

Assim é que se pode inferir que Paulo reprovou uma atitude muito comum de seu público: o politeísmo e a representação imagética dos deuses do panteão grego.

O religioso enfoca os fatos presentes onde ele e o seu auditório eram as personagens da ação. O apóstolo se vale de um objeto de culto dos atenienses (vers. 23) e inicia a sua prédica falando a respeito da criação do Universo pelo "Deus Desconhecido" entre outras coisas (vers. 24-27).

Depois, ele e o seu auditório, novamente, são as personagens da ação (vers. 28). Retorna a falar, mais uma vez, do "Deus Desconhecido", faz referência a um varão, Jesus Cristo (vers. 29-31). A propósito, no final do discurso, tem-se uma prolepse, quando Paulo menciona a respeito de um julgamento do "Deus Desconhecido" que está para acontecer "por meio de um 
varão" (vers. 31) e, após a prolepse, tem-se uma analepse, uma vez que o narrador se volta para o passado ao falar sobre a ressurreição "de um varão" (vers. 31).

Desse modo, Paulo preferiu um discurso em que as instâncias da enunciação se alternavam. Convém aqui, lembrar, mais uma vez, Aristóteles, que diz não ser a narração, no gênero epidíctico, "de modo sucessivo / um após o outro", mas dividida "em partes" (ARISTOTE. Rhétorique, III, 16, 1416 b 17-23).

No discurso paulino, nas Escadarias da Fortaleza Antônia em Jerusalém (Atos 21. 40; 22. 1-24), Paulo é um narrador secundário intra-homodiegético (quando vivencia os fatos relatados por ele). Tem-se, por exemplo, o emprego de pronomes, de verbos na primeira pessoa do singular, enfim, de expressões em que Paulo se insere no próprio relato: "minha" (vers. 1); «Eu sou", "nascido", «educado", "instruído", "dedicado a Deus" (vers. 3); "persegui” (vers. 4); "me", "comecei a caminhar", "após ter recebido", "na intenção de trazer" (vers. 5); "aconteceu-me", "caminhando e aproximando", "ao meu redor" (vers. 6); "caí", "ouvi", “dizendo-me" (vers. 7); "eu respondi", "me" (vers. 8); "comigo" (vers. 9); "Respondi”, "farei", "me" (vers. 10); "não era capaz de ver", "após ter sido conduzido pela mão", "comigo", "cheguei" (vers. 11); "até mim", "a mim", "E eu", "levantei os olhos" (vers. 12); "Aconteceume", "após ter retornado", "e eu suplicando no templo", "encontrar-me" (vers. 17);"a mim" (vers. 18), "E eu respondi", "eu estava", "aprisionando e açoitando" (vers. 19); "eu mesmo estava presente", "concordando e guardando" (vers. 20); "me" (vers. 21).

É bom lembrar que Lucas, o narrador primário, faz a introdução para inserir o discurso mimético paulino (At 21. 40), mas, após dar "voz" ao narrador secundário Paulo (At 22. 1), Lucas interrompe para dar maiores informações em um discurso narrativizado (At 22. 2) e, só então, retorna para o discurso mimético nos versículos subsequentes, deixando, dessa vez, o discurso mimético de Paulo fluir normalmente. Apesar dessa pequena intromissão por parte do narrador primário no início do discurso paulino, pode-se também dizer que o discurso nas escadarias da Fortaleza Antônia em Jerusalém constitui uma narrativa de focalização interna, uma vez que Paulo, o narrador secundário é o sujeito da enunciação.

Os ouvintes são narratários secundários intra-heterodiegéticos, em grande parte do discurso, pois escutam um relato de acontecimentos em que não tiveram participação. Não obstante, por um breve momento, os ouvintes são intra-homodiegéticos, uma vez que Paulo insere o seu público no relato, por meio do adjetivo "todos", do pronome pessoal, na segunda pessoa do discurso, "vós", e do verbo, igualmente, na segunda pessoa do discurso: "sendo dedicado a Deus, da mesma maneira que todos vós sois hoje" (At 22. 3).

Pelo fato de o apóstolo estar em Jerusalém, constrói o seu êthos logo no início do discurso, para fazer com que a imagem desfavorável, que os seus ouvintes tinham dele, a de ser um sacrílego, fosse dissipada, conforme os versículos subscritos:

[3] Eu sou varão judeu, nascido em Tarso da Cilícia, mas educado nesta cidade, instruído junto aos pés de Gamaliel de acordo com a exatidão da lei paterna; dedicado a Deus da mesma maneira que todos vós sois hoje (At 22.3).

Paulo valoriza, principalmente, o seu êthos onde engrandece a sua formação acadêmica/teológica e os seus diálogos com seus dois interlocutores, Jesus e Ananias. Assim, Paulo amplifica e valoriza esses fatos com vistas à persuasão de seu público hierosolimitano.

\section{Referências}


ALAND, Kurt et alli. O Novo Testamento Grego. Barueri, São Paulo: Sociedade Bíblica do Brasil, 2007.

ARISTOTE. Rhétorique. Texte Établi et Traduit par Médéric Dufour e André Wartelle. Paris: Les Belles Lettres, 1973, Tome Troisième.

BAILLY, Anatole. Dictionnaire Grec-Français. Ed. Revista par L. Séchan e Chantraine. Paris: Hachette, 2000.

BARTHES, Roland. A Retórica Antiga. In: COHEN, Jean et alli. Pesquisas de Retórica. Tradução de Leda Pinto Mafra Iruzun. São Paulo: Editora Vozes, 1975, pp. 147-225.

, Roland. Introdução à Análise Estrutural da Narrativa. In: BARTHES, Roland et alli. Análise Estrutural da Narrativa. Tradução de Maria Zélia Barbosa Pinto. Petrópolis, RJ: Vozes, 2011, pp. 19-62.

BENVENISTE, Émile. O Homem na Linguagem. Tradução de Isabel Maria Lucas Pascoal. Lisboa: Vega, s/d.

BÍBLIA DE ESTUDO GENEBRA (Edição Revista e Ampliada). Tradução de João Ferreira de Almeida. São Paulo: Sociedade Bíblica do Brasil, 1999.

BRAIT, Beth. A Personagem. São Paulo: Ática, 1990.

CASTRO, Manuel Antônio de. Mimésis. In: SAMUEL, Rogel (Org.). Manual de Teoria Literária. Petrópolis: Vozes, 1986, pp. 56-59.

DUBOIS, J., EDELINE, F., KLINKENBERG, J.M., MINGUET, P., PIRE, F., TRINON, H. Rhétorique Générale. Paris: Larousse, 1970.

GENETTE, Gérard. Discurso da Narrativa. Tradução de Fernando Cabral Martins, Lisboa: Vega, 1995.

Gérard. Fronteiras da Narrativa. In: BARTHES, Roland et alli. Análise Estrutural da Narrativa. Tradução de Maria Zélia Barbosa Pinto. Petrópolis, RJ: Vozes, 2011, pp. 265-284.

HOMÈRE. Iliade. Texte Établi et Traduit par Paul Mazon (Tome 1, Chants I à XII). Paris: Société D’ Édition Les Belles Lettres, 1937.

MAINGUENEAU, Dominique. Termos Chave da Análise do Discurso. Tradução de Márcio Venício Barbosa e Maria Emília A. T. Lima. Belo Horizonte, Editora UFMG, 1986.

MESCHONNIC, Henri. Les Etats de la Poétiqué. Paris, France: Puf Écriture, 1985.

MESQUITA, Samira Nahid de. O Enredo. São Paulo: Ática, 1987.

PLATO. Republic. In: Platonis Opera, Ed. of John Burnet. Oxford University Press, 1903. Disponível em: http://www.perseus.tufts.edu/hopper/text?doc=Perseus:text:1999.01.0167. Acesso em: 12 /04/ 2013. 
PLUTARCH. Quaestiones Convivales. Ed. of Gregorius N. Bernardakis. Disponível em: http://www.perseus.tufts.edu/hopper/text?doc=Perseus\%3Atext\%3A2008.01.0311\%3Astephp age\%3D706e. Acesso em: 10/11/2013.

TODOROV, Tzvetan. As Estruturas Narrativas. Tradução de Leyla Perrone-Moisés. São Paulo: Perspectiva, 2011 a.

Tzvetan. As Categorias da Narrativa Literária. In: BARTHES, Roland et alli. Análise Estrutural da Narrativa. Tradução de Maria Zélia Barbosa Pinto. Petrópolis, RJ: Vozes, 2011 b, pp. 218-264. 